\title{
Novel Peptides of Therapeutic Promise from Indian Conidae
}

\author{
K. HANUMAE GOWD ${ }^{a}$ V. SABAREESH, ${ }^{b}$ S. SUDARSLAL, ${ }^{b}$ \\ PRATHIMA IENGAR,${ }^{b}$ BENJAMIN FRANKLIN,${ }^{c}$ ANTONY FERNANDO, ${ }^{c}$ \\ KALYAN DEWAN,${ }^{d}$ MANI RAMASWAMI,${ }^{e}$ SIDDHARTHA P. SARMA,${ }^{f}$ \\ SUJIT SIKDAR,${ }^{b}$ P. BALARAM,${ }^{b}$ AND K.S. KRISHNAN ${ }^{a, f}$ \\ ${ }^{a}$ Tata Institute of Fundamental Research, Mumbai, India \\ ${ }^{b}$ Molecular Biophysics Unit, Indian Institute of Science, Bangalore, India \\ ${ }^{c}$ C A S in Marine Biology, Annamalai University, Porto Novo, India \\ ${ }^{d}$ Unichem R\&D Center, IISc Campus, Bangalore, India \\ ${ }^{e}$ Institute of Neuroscience, Trinity College, Dublin, Ireland

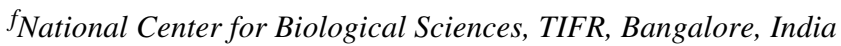

\begin{abstract}
Highly structured small peptides are the major toxic constituents of the venom of cone snails, a family of widely distributed predatory marine molluses. These animals use the venom for rapid prey immobilization. The peptide components in the venom target a wide variety of membrane-bound ion channels and receptors. Many have been found to be highly selective for a diverse range of mammalian ion channels and receptors associated with painsignaling pathways. Their small size, structural stability, and target specificity make them attractive pharmacologic agents. A select number of laboratories mainly from the United States, Europe, Australia, Israel, and China have been engaged in intense drug discovery programs based on peptides from a few snail species. Coastal India has an estimated $20-30 \%$ of the known cone species; however, few serious studies have been reported so far. We have begun a comprehensive program for the identification and characterization of peptides from cone snails found in Indian Coastal waters. This presentation reviews our progress over the last 2 years. As expected from the evolutionary history of these venom components, our search has yielded novel peptides of therapeutic promise from the new species that we have studied.
\end{abstract}

KEYwORDs: novel peptides; Conidae; molluscs; contryphans

\section{INTRODUCTION}

Legend has it that Jeevaka defended his thesis in the seventh century BC with the following remarks. "Human diseases manifest an imbalance of bodily functions and since poisons of various kind kill by affecting one or the other bodily functions, they

Address for correspondence: K.S. Krishnan, Department of Molecular Biology, Tata Institute of Fundamental Research, Colaba, Mumbai, 40005, India

ksk@mailhost.tifr.res.in

Ann. N.Y. Acad. Sci. 1056: 462-473 (2005). (C) 2005 New York Academy of Sciences. doi: 10.1196/annals.1352.022 
could be drugs for treatment of disorders if used judiciously." Jeevaka was known in ancient times for some of the most astounding cures and later became Buddha's personal physician. This story in some manner points to great interest in the analysis of plant and animal toxins as starting points for drug discovery. Ayurveda and other traditional medicine systems around the world generally use plant-derived material as cures. Rare, however, are examples of animal venom and toxins as prospective drugs.

Animals use venom for both prey capture and defense. In particular, a weak and slow moving animal is more or less likely to target the enemy or prey species' nervous system because of the need for rapid immobilization. Marine cone snails represent one such class, are the largest single genus of venomous predators, estimated at about 500 species, and are widely distributed in the Indo-Pacific. ${ }^{1}$ They prey on fish, marine worms, and molluscs. ${ }^{2}$ Cone snails have evolved mechanisms to generate a library of toxic peptides, which act in concert to rapidly immobilize prey by simultaneously targeting several receptors and channels. Specific cabals of toxins have been identified in some cases. ${ }^{2,3}$ In nearly 20 years, primarily due to the work of Baldomero Olivera, conotoxins have become a promising source of drug discovery in addition to becoming a major new paradigm for evolutionary studies. ${ }^{4}$ Conotoxins target voltage-gated and ligand-gated ion channels as well as G-proteincoupled receptors with high specificity and selectivity. ${ }^{5}$ Several conus peptides are widely used as research tools in neuroscience, such as w-conotoxin, and some are potential therapeutic agents, such as Ziconotide. ${ }^{6,7}$ The approximately 150 conotoxins reported to date represent less than $0.3 \%$ of peptides present in the venom of conidae. Clearly, many therapeutically interesting molecules remain to be isolated and characterized from the genus conus.

The conidae of India are of particular interest because of the availability of about 77 species, 21 of which are unique. ${ }^{8}$ We have initiated a comprehensive program of investigating the chemistry and pharmacology of conus peptides derived from the cone snails found off the coast of India. This report describes some of our research over the last 3 years.

\section{SPECIES ABUNDANCE}

From our initial surveys in India, we found that many cone snail species are available near Mumbai. During routine collection trips, we obtained live specimens of about 40 different species. Of these, 7 abundant species are the subject of our studies (FIG. 1). Cone snails are classified into three major groups according to their prey preference: the piscivorous preying upon fish (C. achatinus), the mollusci-vorous eating molluscs (C. amadis, $C$. araneosus), and the vermivorous feeding on polychaete worms ( $C$. inscriptus, $C$. loroisii, and $C$. hyaena hyaena). We have also done a systematic study of the Radula-tooth of 25 of the available species. A comparative analysis showed clear-cut differences in the radula structure of piscivorous, molluscivorous, and vermivorous snails. ${ }^{9}$ It is hoped that these studies will help to classify newly identified species (B. Franklin, A. Fernando, and K.S. Krishnan, unpublished data). An example of the comparison of radula-teeth structures of vermi-vorous and piscivorous snails is shown in FIGURE 1. 


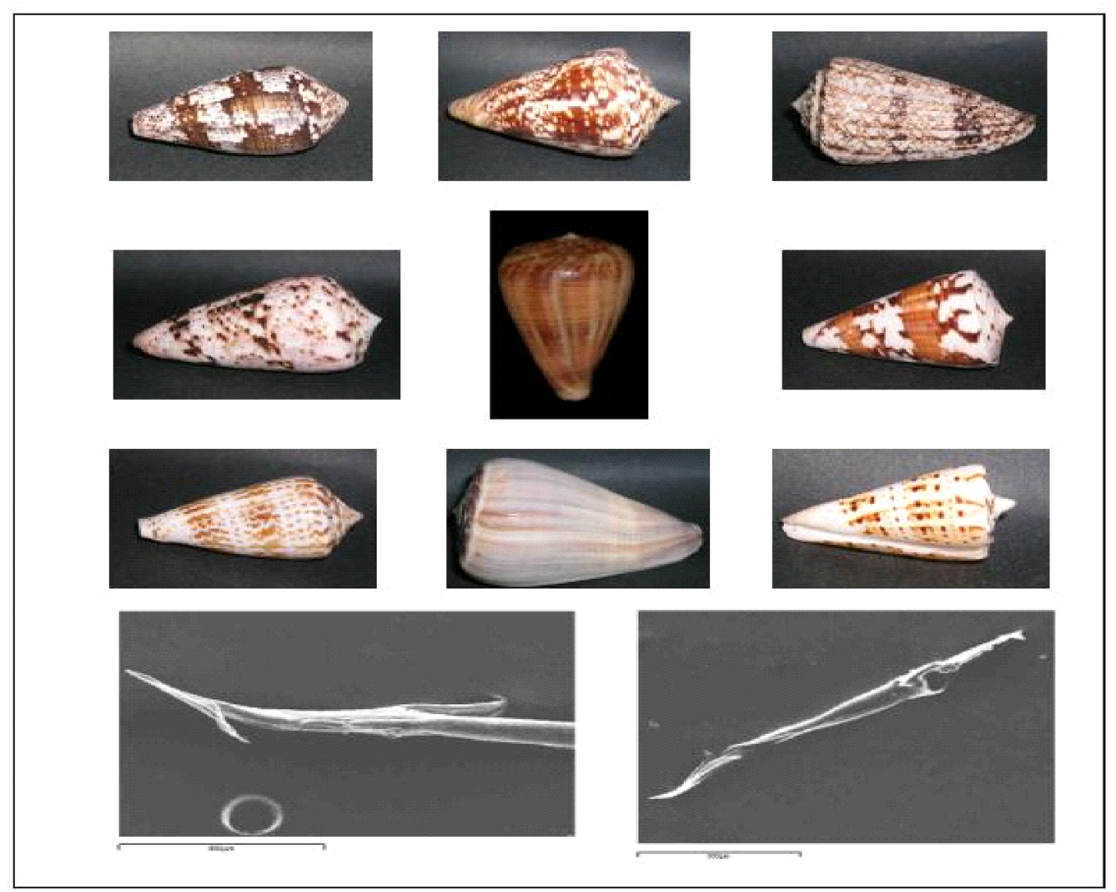

FIGURE 1. A collection of Indian cone shells. From left to right: (top row) C. achatinus, C. amadis, and C. araneosus. (Second row) C. zeylanicus, C. hyaena hyaena, and C. malacanus. (Third row) C. inscriptus, C. loroisii, and C. monile. (Bottom row) SEM picture of radula tooth from $C$. achatinus (piscivorous) and $C$. hyaena hyaena (vermivorous).

\section{ISOLATION AND CHARACTERIZATION OF PEPTIDES}

In the first phase of the investigation we focused primarily on peptides that can be extracted into organic solvents such as methanol and acetonitrile. The toxic components of conus venoms are mostly small peptides ranging in size from 10-50 amino acids. ${ }^{5-10} \mathrm{~A}$ large fraction of these peptides have multiple disulfide bonds. In addition, they contain several posttranslational modifications including $\mathrm{C}$-terminal amidation, proline hydroxylation, and epimerization of specific residues, in the case of contryphans. ${ }^{11}$ MALDI-MS provides a convenient tool for fingerprinting the peptide components of conus venom and for monitoring HPLC purification of complex peptide mixtures. FIGURE 2 shows the MALDI-MS obtained by spotting the venom sample directly mixed with the matrix.

Comparison of the spectra generated in the range of 1,000-4,000 Da clearly indicates pronounced differences in the components. In this mass range, the peaks are invariably derived from peptide components. FIGURE 3 shows a typical RP-HPLC 


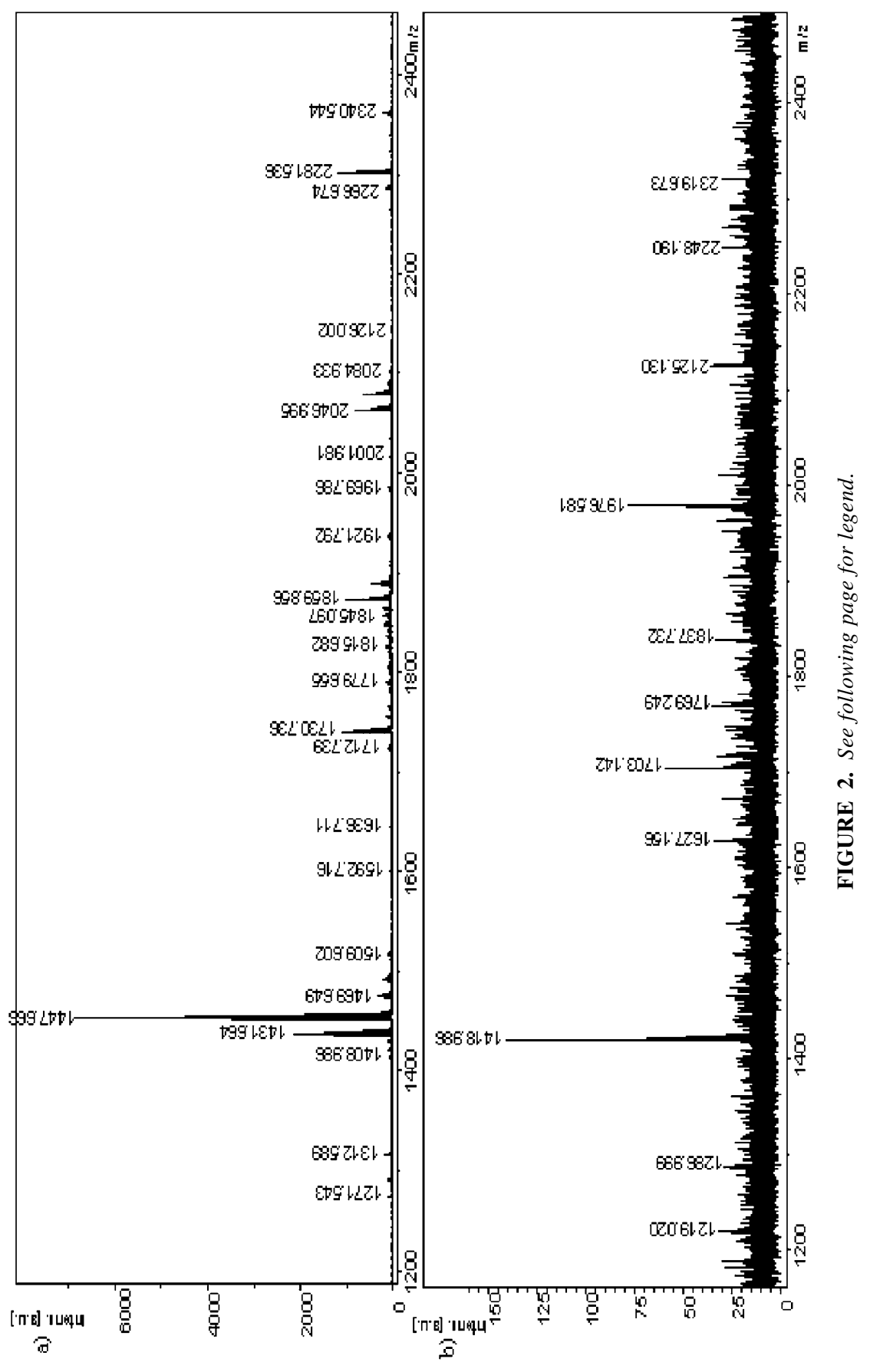


separation of the venom components from $C$. araneosus. Peptides widely differing in mass can coelute in a single symmetrical peak, often necessitating multiple rounds of purification.

Further characterization of venom peptides requires determination of the amino acid sequence. Tandem mass spectrometry is especially powerful for peptides of this size. In our studies, we employed both MALDI-TOF/TOF and ESI-Ion trap methods. FIGURE 4a shows a typical fragmentation spectrum obtained in a MALDI-MS/MS experiment. Before fragmentation, the peptide must be reduced (dithithreitol) and alkylated (iodoacetamide) in order to break all the covalent disulfide cross-links. Sequence determination can be achieved if suitable series of $b_{n}$ and $y_{n}$ ions are observed, as shown in FIGURE 4a. ${ }^{12}$ Mass spectrometric sequencing of peptides is facilitated by using chemical modification experiments, enzymatic digestion, and multiple reduction/alkylation combinations in breaking disulfide bonds. Confirmation of the sequence usually requires examination of the fragmentation in an ion trap spectrometer. FIGURE $4 \mathrm{~b}$ illustrates the ESI-MS/MS spectrum obtained for the peptide Ar1312 from $C$. araneosus. Inspection of FIGURE 4 reveals the presence of hydroxyproline, which results in the intense $y_{2}$ ion detected at 292 Da due to preferential cleavage of the Xxx-Hyp tertiary amide bond.

Mass spectral sequencing can lead to ambiguities in assignment of amino acid residues in some cases. The final confirmation of a determined sequence may be achieved by comparing a chemically synthesized peptide with the natural peptide. FIGURE 5a and $\mathrm{b}$ illustrates a comparison of the MALDI-MS/MS of reduced/alkylated natural Ar1312 and alkylated synthetic Ar1312, respectively. Both peptides have identical masses of 1,544 Da. The observed spectra revealed the identity of all major fragments, thus confirming the sequence. An analog of Ar1312, which contains asparagine in the place of hydroxyproline, with the C-terminus amidated instead of the free carboxylic acid, was synthesized. The choice of this analog was based on the frequent observation of C-terminal amidation in the conotoxins. This analog (alkylated) also has a mass of 1,544 Da. The mass spectral fragmentation pattern (FIG. 5c) reveals important differences from the natural peptide. The spectrum of the natural peptide contains a $y_{2}$ ion at $292 \mathrm{Da}$, which is absent in the Asn analog. Thus, mass spectrometry in conjugation with chemical synthesis can provide a means of establishing the amino acid sequences of peptides isolated from Conus venom. TABLE 1 provides representative examples of new sequences determined from Indian cone snails. Identification of the novel 13-residue peptide from C. monile (Mo 1659), which lacks disulfide bonds, provides an example of a new peptide family. This clearly indicates that exhaustive investigations of Conus venoms from diverse species may yet yield many novel sequences.

FIGURE 2. MALDI-MS of (a) crude venom of C. araneosus and (b) acetonitrile extract of $C$. loroisii. MALDI spectra were collected using a Bruker Daltonics, Ultraflex TOF/ TOF system, in the reflectron-positive ion mode, equipped with a nitrogen laser of $337 \mathrm{~nm}$. Samples were prepared by mixing equal volumes of venom or a crude acetonitril extract with the MALDI matrix (a-cyano-4-hydroxy cinnamic acid). 


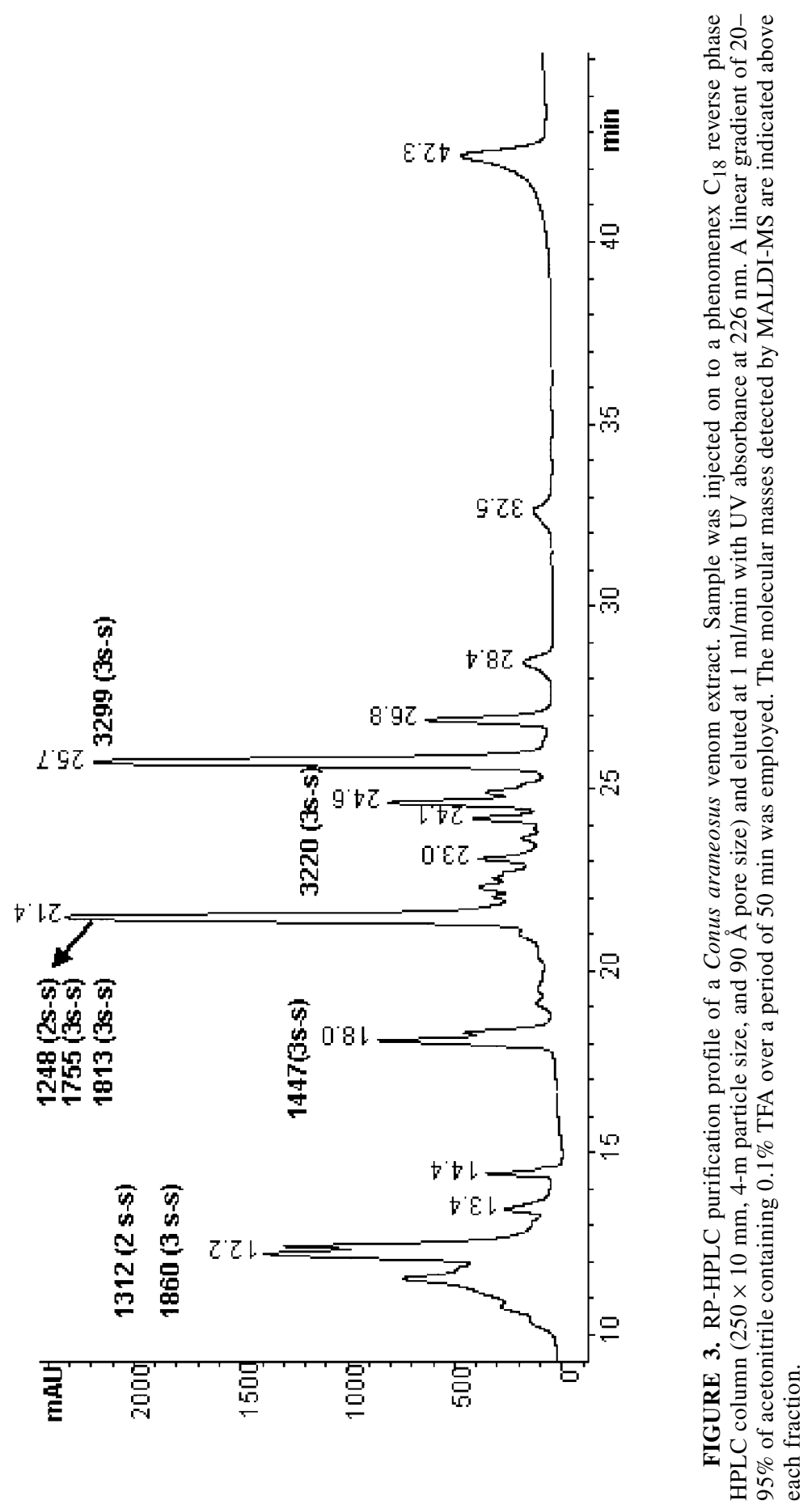




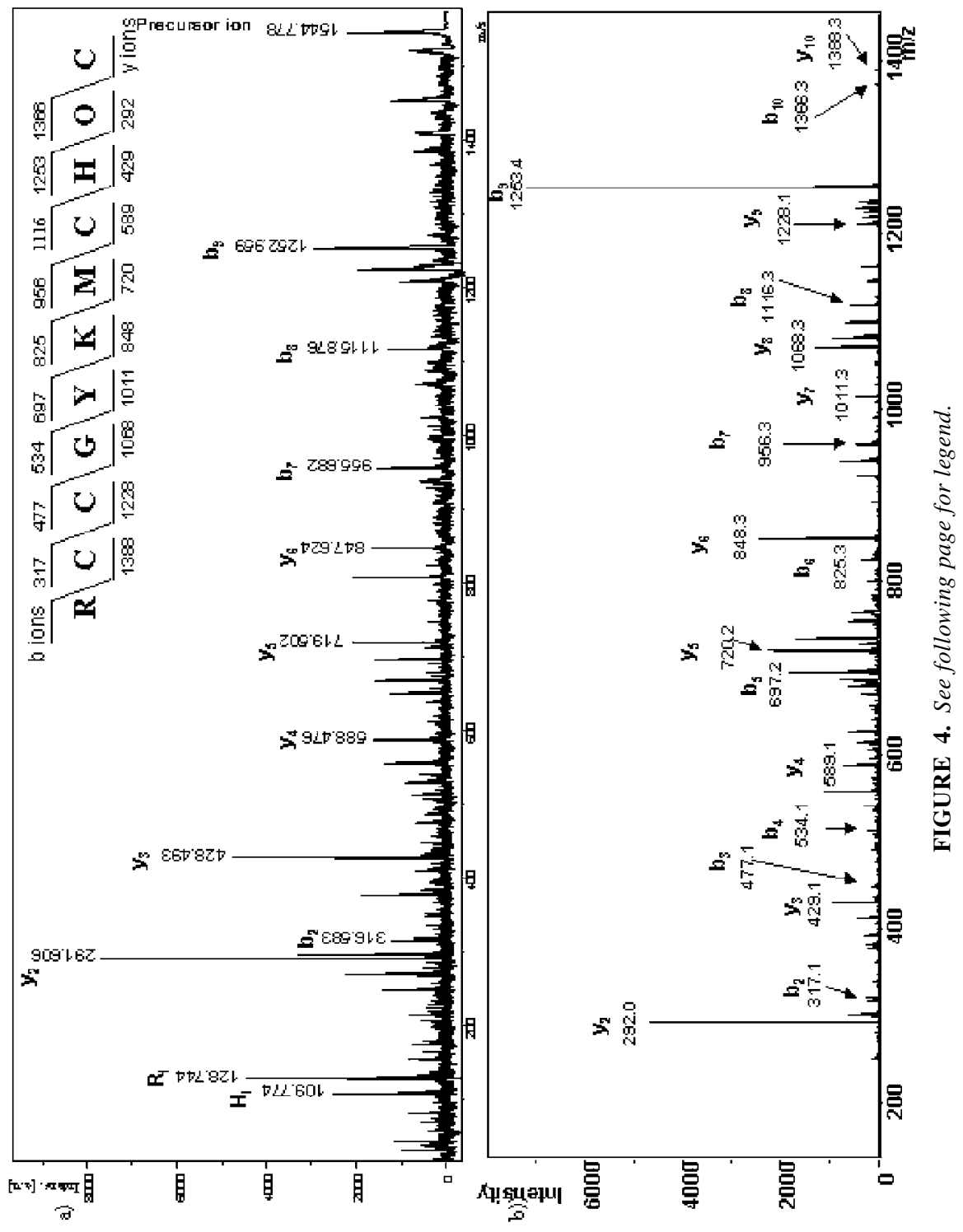


TABLE 1. Novel conotoxins isolated from Indian marine cone snails

\begin{tabular}{lcccc}
\hline \multicolumn{1}{c}{$\begin{array}{c}\text { Conus } \\
\text { species }\end{array}$} & Sequence & $\begin{array}{c}\text { Name of } \\
\text { peptide }\end{array}$ & Target & Ref. \\
\hline $\begin{array}{l}\text { C. } \text { amadis } \\
\text { (mollusc hunter) }\end{array}$ & $\begin{array}{c}\text { CKQAGESCDIFSQNC- } \\
\text { CVGTCAFICIE-NH }\end{array}$ & Am2766 & $\begin{array}{c}\text { Mammalian } \\
\text { sodium } \\
\text { channel }\end{array}$ & 13 \\
$\begin{array}{l}\text { C. monile } \\
\text { (worm eater) }\end{array}$ & FHGGSWYRFPWGY-NH 2 & Mo1659 & $\begin{array}{c}\text { Potassium } \\
\text { channel }\end{array}$ & 14 \\
$\begin{array}{l}\text { C. } \text { loroisii } \\
\text { (worm eater) }\end{array}$ & GCPDWDPWC-NH & Lo959 & $\begin{array}{c}\text { Under investi- Unpub- } \\
\text { gation }\end{array}$ & \begin{tabular}{c} 
lished \\
\hline
\end{tabular} \\
\hline
\end{tabular}

\section{CONTRYPHAN}

Contryphans are an interesting class of conus peptides containing a single disulfide bond. They are generally 7-9 residues in length and contain a D-amino acid residue, which is separated from the N-terminal cysteine by a single amino acid. ${ }^{15}$ Epimerization occurs posttranslationally. Novel conformational equilibria have also been reported for contryphans. ${ }^{16}$ Contryphans are sometimes easily detected in crude venom by the observation of masses in the range of 900-1,000 Da. In the course of our studies we determined the sequences of the contryphans from Conus amadis, $C$. loroisii, and $C$. inscriptus. TABLE 2 provides a comparison of mature contryphan sequences determined thus far.

The contryphan Am975 from C. amadis is identical to that of contryphan-P characterized from C. purpurascens. ${ }^{16}$ The presence of a D-residue in the peptide from C. loroisii Lo959 was established by comparing the chromatographic profile of the natural peptide with two chemically synthesized analogs, which contain L-Trp or DTrp at position 4. FIGURE 6 shows that the HPLC profile of natural Lo959 is identical to that obtained from the synthetic analog containing the D-residue at position 4 . By contrast, the L-analog reveals a distinctly different HPLC profile. A curious feature of the Lo959 HPLC profile is the presence of two peaks, separated by a broad trough. Isolation of each of these peaks followed by re-injection yields the same chromatogram. Similar behavior was also obtained for the synthetic peptide containing D-Trp at residue 4 . A previous study by Olivera and co-workers ${ }^{17}$ showed that contryphan exists in two distinct conformational states, which interconvert slowly on the chromatographic time scale. This conformational process is characteristic of peptides, which contain both D-Trp and the disulfide bond. A preliminary study in our labo-

FIGURE 4. Fragment ion mass spectrum of Ar1312. (a) MALDI-MS/MS and (b) ESIMS/MS. The masses of $\mathrm{b}$ and $\mathrm{y}$ ions according to the proposed sequence are shown above. $\mathrm{H}_{\mathrm{i}}$ and $\mathrm{Ri}$ indicates the immonium ions of histidine and arginine, respectively. MALDI-MS/ MS data were obtained using the LIFT option of Bruker Daltonics. Precursor ion at $\mathrm{m} / \mathrm{z} 1554$ Da was trapped and its fragmentation induced. ESI-MS/MS data were obtained on Esquire 3000 plus LC ion trap mass spectrometer (Bruker Daltonics, Germany). The singly charged precursor ion at $\mathrm{m} / \mathrm{z} 1544 \mathrm{Da}$ was selected in an ion-trap system and subjected to highenergy collision-induced dissociation (CID) with helium as a collision gas. 


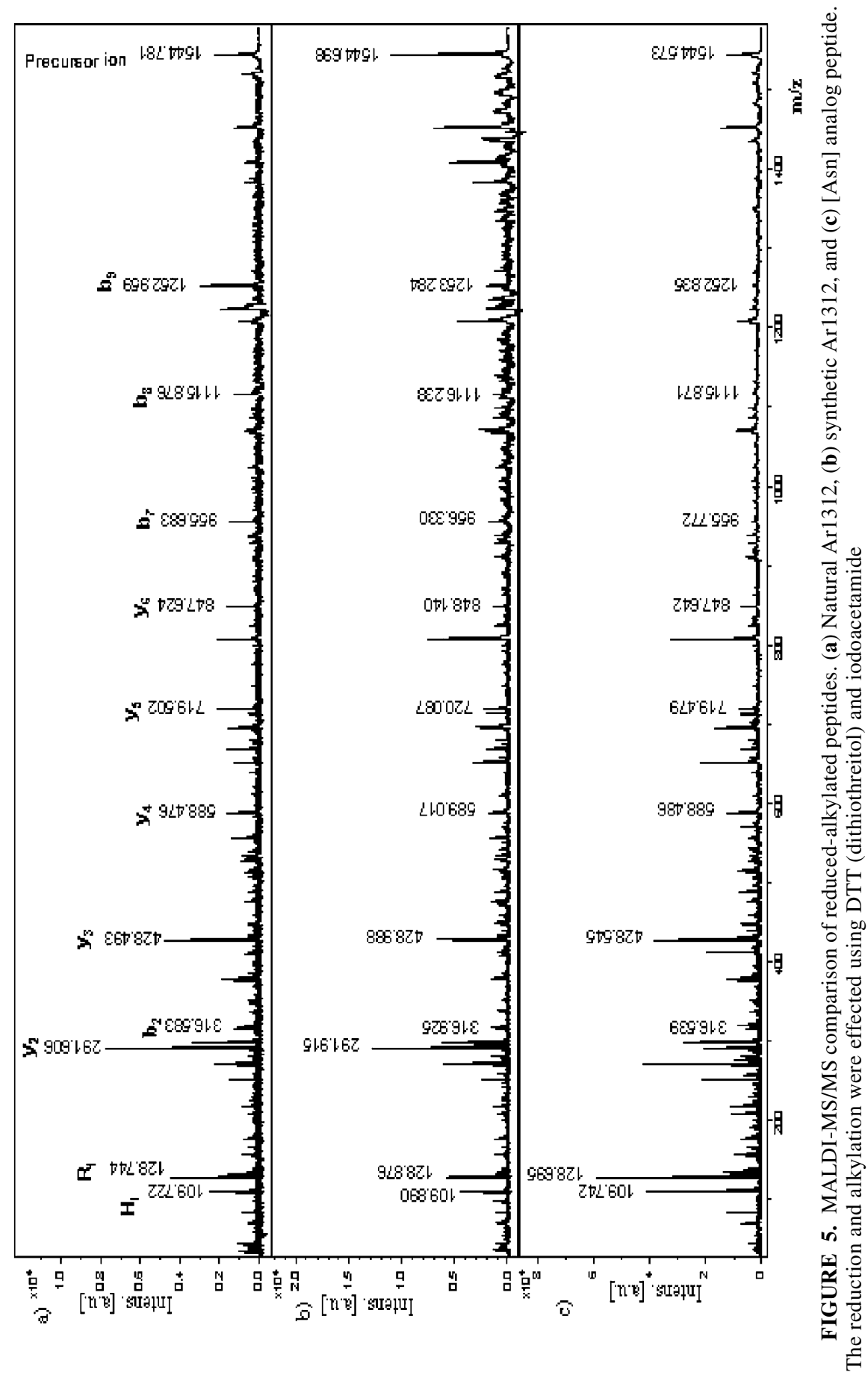




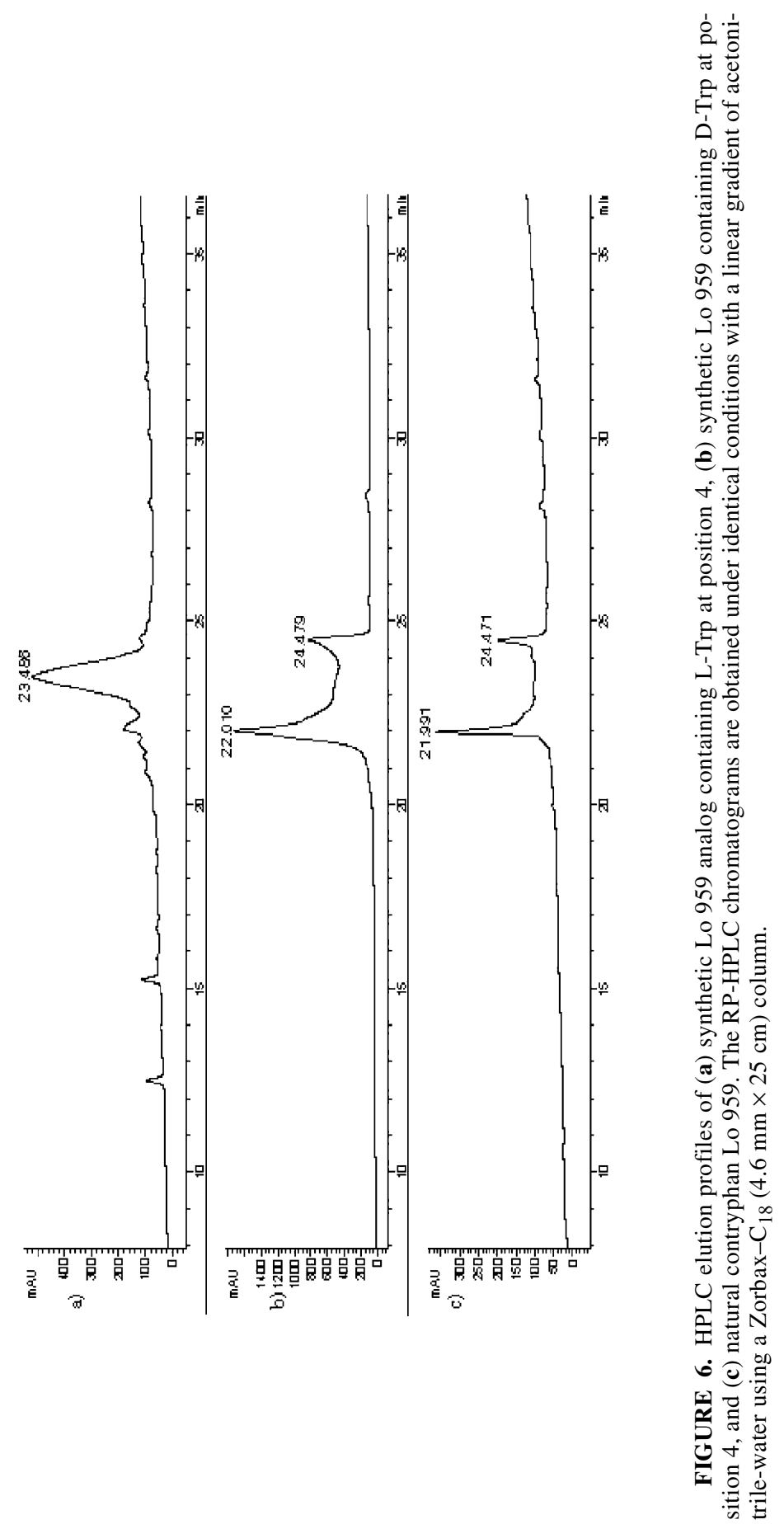


TABLE 2. Comparison of mature contryphan sequences ${ }^{a}$

\begin{tabular}{|c|c|c|c|}
\hline Peptide & Sequence & Species & Ref. \\
\hline Des(Glyl)contryphan-R & $\mathrm{CO} \underline{\mathrm{WEPWC}}-\mathrm{NH}_{2}$ & C. radiatus & 15 \\
\hline Contryphan-R & GCOWEPWC-NH ${ }_{2}$ & C. radiatus & 15 \\
\hline Bromocontryphan-R & GCOWEPXC-NH ${ }_{2}$ & C. radiatus & 18 \\
\hline Contryphan-Sm & GCOWQPWC-NH & C. stercusmuscarum & 16 \\
\hline Contryphan-P & GCOWDPWC-NH ${ }_{2}$ & C. purpurascens & 16 \\
\hline Contryphan-R/Tx & GCOWEPWC-NH ${ }_{2}$ & C. textile & 20 \\
\hline Contryphan-Tx & GCOWQPYC-NH & C. textile & 20 \\
\hline Contryphan-Vn & GDCPWKPWC-NH ${ }_{2}$ & C. ventricosus & 21 \\
\hline Leu-Contryphan-P & GCVLLPWC-OH & C. purpurascens & 17 \\
\hline Leu-Contryphan-Tx & CVLYPWC-NH ${ }_{2}$ & C. textile & 20 \\
\hline Glacontryphan-M & $\mathrm{N} \gamma \mathrm{S} \gamma \mathrm{CP} \underline{\mathrm{WHPWC}}-\mathrm{NH} 2$ & C. marmoreus & 22 \\
\hline Contryphan-P/Am & GCOWDPWC-NH ${ }_{2}$ & C. amadis & This work \\
\hline Contryphan-Lo & GCPWDPWC-NH ${ }_{2}$ & C. loroisii & This work \\
\hline Contryphan-In & GCVLYPWC-NH 2 & C. inscriptus & This work \\
\hline
\end{tabular}

Note: O, 4-trans-hydroxyproline; $\underline{\mathrm{W}}$, D-tryptophan; $\underline{\mathrm{L}}$, D-leucine; $\underline{\mathrm{X}}$, bromotryptophan; $\gamma$, gamma-carboxyglutamic acid.

ratory suggests that the contryphan Am 975 acts predominantly on the high-voltage activated calcium channel.

Ongoing studies in our laboratory are focused on mass spectral determination of a specific disulfide-bonding pattern, chemical synthesis of a multiple disulfidebonded peptide, and three-dimensional structure determination using two-dimensional NMR. ${ }^{23}$ The oxidative folding of chemically synthesized sequences containing multiple cysteine residues results in the formation of peptides with non-native disulfide bonding. ${ }^{24} \mathrm{We}$ are also pursuing the determination of cDNA sequences corresponding to a specific conotoxin superfamily obtained from freshly dissected venom glands.

\section{ACKNOWLEDGMENTS}

This research was supported by a grant from the Department of Biotechnology, Government of India, at the National Center for Biological Sciences, TIFR, Molecular Biophysics Unit, IISc and Center for Advanced Studies, Annamalai University.

\section{REFERENCES}

1. Rockeld, K.W. \& A.J. Kohn. 1995. Manual of the Living Conidae. Verlag Christa Hemmen. Wiessbanden, Germany. 
2. Olivera, B.M. 1997. Conus venom peptides, receptor and ion channel targets and drug design: 50 million years of neuropharmacology (EE Just Lecture, 1996). Mol. Biol. Cell 8: 2101-2109.

3. Olivera, B.M., J.S. Imperial \& G. Bulaj. 2002. Cone snails and conotoxins: evolving sophisticated neuropharmacology. In Perspectives in Molecular Toxinology. A. Menez., Ed. Wiley. West Sussex, UK.

4. HeinRich, T. \& B.M. Olivera. 2004. Conus venoms: a rich source of novel ion channels-targeted peptides. Physiol. Rev. 84: 41-68.

5. Myers, R.A. et al. 1993. Conus peptides as chemical probe for receptor and ion channels. Chem. Rev. 93: 1923-1936.

6. AdAms, M.E. \& B.M. Olivera. 1994. Neurotoxins: overview of an emerging research technology. TINS 17: 151-155.

7. JONES, R.M. et al. 2001. Composition and therapeutic utility of conotoxins from genus Conus. Patent status 1996-2000. Exp. Opin. Ther. Patents 11: 603-623.

8. Kohn, A.J. 2001. The Conidae of India revisited. Phuket Marine Biological Center Special Publication 25: 357-362.

9. KoHn, A.J., M. Nishi \& B. Pernet. 1999. Snail spears and scimitars: a character analysis of Conus radula teeth. J. Moll. Stud. 65: 461-481.

10. Kohn A.J., P.R. SAunders \& S. Wiener. 1960. Preliminary studies on the venom of the marine snail conus. Ann. N.Y. Acad. Sci. 90: 706-725.

11. Craig, A.G., P. Bandyopadhyay \& B.M. Olivera. 1999. Post-translationally modified neuropeptides from conus venoms. Eur. J. Biochem. 264: 271-275.

12. BiemanN, K. 1990. Sequencing of peptides by tandem mass spectrometry and highenergy collision-induced dissociation. Methods Enzymol. 193: 455-479.

13. SudARSLAL, S. et al. 2003. Sodium channel modulating activity in a delta-conotoxin from an Indian marine snail. FEBS Lett. 553: 209-212.

14. Sudarslal, S. et al. 2004. A novel 13 residue acyclic peptide from the marine snail, Conus monile, targets potassium channels. Biochem. Biophys. Res. Commun. 317: $682-688$.

15. JimeneZ, E.C. et al. 1996. Contryphan is a D-tryptophan-containing Conus peptide. J. Biol. Chem. 271: 28002-28005.

16. JACOBSEN, R. et al. 1998. The contryphans, a D-tryptophan-containing family of Conus peptides: interconversion between conformers. J. Pept. Res. 51: 173-179.

17. JaCOBSEN, R.B. et al. 1999. A novel D-leucine-containing Conus peptide: diverse conformational dynamics in the contryphan family. J. Pept. Res. 54: 93-99.

18. JiMENEZ, E.C. et al. 1997. Bromocontryphan: post-translational bromination of tryptophan. Biochemistry 36: 989-994.

19. JACOBSEN, R. et al. 1998. The contryphans, a D-tryptophan-containing family of Conus peptides: interconversion between conformers. J. Pept. Res. 51: 173-179.

20. Jimenez, E.C. et al. 2001. Contryphans from Conus textile venom ducts. Toxicon 39: 803-808.

21. MassiLia, G.R. et al. 2001. Contryphan-Vn: a novel peptide from the venom of the Mediterranean snail Conus ventricosus. Biochem. Biophys. Res. Commun. 288: 908-913.

22. HANSSON, K. et al. 2004. The first gamma-carboxyglutamic acid containing contryphan A selective L-type calcium ion channel blocker isolated from the venom of Conus marmoreus. J. Biol. Chem. 279: 32453-32463.

23. SARMA, S.P. et al. 2005. Solution structure of d-Am2766: a hydrophobic d-conotoxin from Conus amadis that inhibits inactivation of neuronal voltage-gated sodium channels. Chem. Biodiversity 2 : in press.

24. Cruz, D.R. et al. 2003. Detergent-assisted oxidative folding of delta-conotoxins. J. Pept. Res. 61: 202-212. 